\title{
Front Matter: Volume 10355
}

, "Front Matter: Volume 10355," Proc. SPIE 10355, Nanobiosystems: Processing, Characterization, and Applications X, 1035501 (28 September 2017); doi: 10.1117/12.2296969

SPIE Event: SPIE Nanoscience + Engineering, 2017, San Diego, California, United SPIE. States 


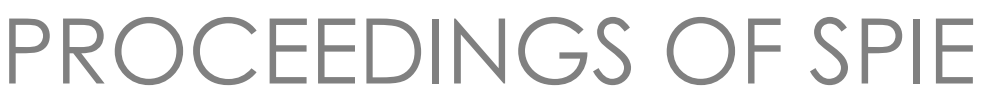

\title{
Nanobiosystems: Processing, Characterization, and Applications $X$
}

\author{
Norihisa Kobayashi \\ Fahima Ouchen \\ lleana Rau \\ Editors
}

9-10 August 2017

San Diego, California, United States

Sponsored and Published by

SPIE 
The papers in this volume were part of the technical conference cited on the cover and title page. Papers were selected and subject to review by the editors and conference program committee. Some conference presentations may not be available for publication. Additional papers and presentation recordings may be available online in the SPIE Digital Library at SPIEDigitalLibrary.org.

The papers reflect the work and thoughts of the authors and are published herein as submitted. The publisher is not responsible for the validity of the information or for any outcomes resulting from reliance thereon.

Please use the following format to cite material from these proceedings:

Author(s), "Title of Paper," in Nanobiosystems: Processing, Characterization, and Applications X, edited by Norihisa Kobayashi, Fahima Ouchen, lleana Rau, Proceedings of SPIE Vol. 10355 (SPIE, Bellingham, WA, 2017) Seven-digit Article CID Number.

ISSN: 0277-786X

ISSN: 1996-756X (electronic)

ISBN: 9781510611672

ISBN: 9781510611689 (electronic)

Published by

SPIE

P.O. Box 10, Bellingham, Washington 98227-0010 USA

Telephone +1 3606763290 (Pacific Time) · Fax +1360647 1445

SPIE.org

Copyright @ 2017, Society of Photo-Optical Instrumentation Engineers.

Copying of material in this book for internal or personal use, or for the internal or personal use of specific clients, beyond the fair use provisions granted by the U.S. Copyright Law is authorized by SPIE subject to payment of copying fees. The Transactional Reporting Service base fee for this volume is $\$ 18.00$ per article (or portion thereof), which should be paid directly to the Copyright Clearance Center (CCC), 222 Rosewood Drive, Danvers, MA 01923. Payment may also be made electronically through CCC Online at copyright.com. Other copying for republication, resale, advertising or promotion, or any form of systematic or multiple reproduction of any material in this book is prohibited except with permission in writing from the publisher. The CCC fee code is 0277$786 \mathrm{X} / 17 / \$ 18.00$.

Printed in the United States of America.

Publication of record for individual papers is online in the SPIE Digital Library.

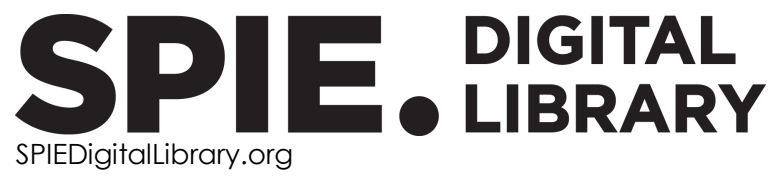

Paper Numbering: Proceedings of SPIE follow an e-First publication model. A unique citation identifier (CID) number is assigned to each article at the time of publication. Utilization of CIDs allows articles to be fully citable as soon as they are published online, and connects the same identifier to all online and print versions of the publication. SPIE uses a seven-digit CID article numbering system structured as follows:

- The first five digits correspond to the SPIE volume number.

- The last two digits indicate publication order within the volume using a Base 36 numbering system employing both numerals and letters. These two-number sets start with 00, 01, 02, 03, 04, 05, 06, 07, 08, 09, 0A, OB ... 0Z, followed by 10-1Z, 20-2Z, etc. The CID Number appears on each page of the manuscript. 


\title{
Contents
}

\author{
$\checkmark$ Authors \\ vii Committee Conference
}

BIOMATERIALS PROPERTIES AND APPLICATIONS

1035503 DNA scaffold nanostructures for efficient and directional propagation of light harvesting cascades (Invited Paper) [10355-2]

\section{DNA APPLICATIONS I}

1035505 Thin film DNA-complex-based dye lasers fabricated by immersion and conventional processes (Invited Paper) [10355-4]

\section{DNA APPLICATIONS II}

10355 OB Colloidal photonic crystals: from lasing to microfluidics (Invited Paper) [10355-10]

\section{POSTER SESSION}

$10355 \mathrm{OL}$ Electrical performances of straight and castellated dielectrophoresis electrodes for biological molecules separation [10355-20]

$10355 \mathrm{OM}$ Effect of different AFM micro cantilever in fluid on the rough surface topography quality close to the surface [10355-21] 
Proc. of SPIE Vol. 10355 1035501-4

Downloaded From: https://www.spiedigitallibrary.org/conference-proceedings-of-spie on 26 Apr 2023 Terms of Use: https://www.spiedigitallibrary.org/terms-of-use 


\section{Authors}

Numbers in the index correspond to the last two digits of the seven-digit citation identifier (CID) article numbering system used in Proceedings of SPIE. The first five digits reflect the volume number. Base 36 numbering is employed for the last two digits and indicates the order of articles within the volume. Numbers start with 00, 01, 02, 03, 04, 05, 06, 07, 08, 09, OA, OB...0Z, followed by 10-1Z, 20-2Z, etc.

Brown, Carl W., III, 03

Buckhout-White, Susan, 03

Buyong, Muhammad R., OL

Clays, Koen, $\mathrm{OB}$

Díaz, Sebastián A., 03

Goldman, Ellen R., 03

H. Korayem, A., OM

H. Korayem, M., OM

Hamzah, Azrul A., OL

Kawabe, Yutaka, 05

Majlis, Burhanuddin Y., OL

Medintz, Igor L., 03

Samanta, Anirban, 03

Song, Kai, OB

Suzuki, Yuki, 05

Walper, Scott A., 03

Yunas, Jumril, OL

Yunus, Farahdiana W., OL

Zhong, Kuo, OB 
Proc. of SPIE Vol. 10355 1035501-6

Downloaded From: https://www.spiedigitallibrary.org/conference-proceedings-of-spie on 26 Apr 2023 Terms of Use: https://www.spiedigitallibrary.org/terms-of-use 


\section{Conference Committee}

Symposium Chairs

Harry A. Atwater Jr., California Institute of Technology (United States)

Nikolay I. Zheludev, Optoelectronics Research Centere

(United Kingdom) and Nanyang Technological University

(Singapore)

Symposium Co-Chairs

James G. Grote, Air Force Research Laboratory (United States)

David L. Andrews, University of East Anglia (United Kingdom)

Conference Chairs

Norihisa Kobayashi, Chiba University (Japan)

Fahima Ouchen, Air Force Research Laboratory (United States)

lleana Rau, University Politehnica of Bucharest (Romania)

Conference Program Committee

Carrie M. Bartsch, Air Force Research Laboratory (United States)

Liming Dai, Case Western Reserve University (United States)

Ananth Dodabalapur, The University of Texas at Austin (United States)

James G. Grote, Air Force Research Laboratory (United States)

Emily M. Heckman, Air Force Research Laboratory (United States)

Kuniharu ljiro, Hokkaido University (Japan)

Jung-II Jin, Korea University (Korea, Republic of)

Francois Kajzar, University Politehnica of Bucharest (Romania)

Sang Nyon Kim, Air Force Research Laboratory (United States)

Oksana Krupka, Université d'Angers (France)

Charles Y. C. Lee, Air Force Office of Scientific Research

(United States)

Misoon Y. Mah, Asian Office of Aerospace Research and

Development (Japan)

Bruce H. Robinson, University of Washington (United States)

Anna Samoc, The Australian National University (Australia)

Marek J. Samoc, Wroclaw University of Technology (Poland)

Niyazi Serdar Sariciftci, Johannes Kepler Universität Linz (Austria)

Kristi M. Singh, Air Force Research Laboratory (United States)

Andrew J. Steckl, University of Cincinnati (United States)

Morley O. Stone, Air Force Research Laboratory (United States)

Guru Subramanyam, University of Dayton (United States)

Perry P. Yaney, University of Dayton (United States) 


\section{Session Chairs}

1 Biomaterials Properties and Applications

James G. Grote, Air Force Research Laboratory (United States)

2 DNA Applications I

André-Jean Attias, Université Pierre et Marie Curie (France)

3 Nanomaterials

Norihisa Kobayashi, Chiba University (Japan)

4 DNA Applications II

lleana Rau, University Politehnica of Bucharest (Romania)

5 DNA Photonics I

Fahima Ouchen, Air Force Research Laboratory (United States)

6 DNA Applications III

François Kajzar, University Politehnica of Bucharest (Romania) 